\title{
Design and Optimization of the Micro-Hydro Power System for Remote Areas of Pakistan
}

\author{
Muhammad Irfan Abid*, Muhammad Shoaib Khalid***, Muhammad Kamran***, Muhammad Arshad \\ Rasheed****, Muhammad Farhan Masood*****, Tasawar Murtaza****** \\ *Department of Electrical Engineering and Technology, Riphah International University, Faisalabad \\ **Department of Electrical Engineering, National University of Computer and Emerging Sciences, Islamabad \\ *** Department of Electrical Engineering and Technology, Riphah International University, Faisalabad \\ **** Department of Electrical Engineering and Technology, University of Engineering and Technology, Faisalabad \\ *****Department of Electrical Engineering, National University of Computer and Emerging Sciences, Islamabad \\ *******Department of Electrical Engineering, National University of Computer and Emerging Sciences, Islamabad
}

(mirfanabid@hotmail.com, shoaib.khalid@nu.edu.pk,kamran_ramzan@outlook.com)

* Corresponding Author; M. Shoaib Khalid, Tel: +92 300965 4781,

Received: 29.06.2020 Accepted:30.09.2020

\begin{abstract}
The electricity price escalation in Pakistan is increasing with an exponential rate because of the dominance of the foreign imported conventional source of energy. The consumer must pay an extra tax as the fuel adjustment in every month's electricity bill. Being the renewable energy source abundant country, Pakistan needs to exploit these energy sources for electricity production. This paper presents a micro-hydro energy system at the Jalala Disty canal in KPK Pakistan. A cite specific scheming of the planned microhydro project is introduced. RETScreen based modeling and optimization of the project are discussed. Net Present Value (NPV) and the Cost of Energy (COE) of the intended microhydro system is calculated. RETScreen optimization assessment confirmed the viability of the planned micro-hydro energy system built on the COE and the NPV. The arrangement is anticipated to retrieve all the expenses incurred in the $4^{\text {th }}$ year of the total period of the planned project. Comparing with the baseline energy mix of the country, the proposed energy project is $100 \%$ greenhouse gases (GHG) emission free project.
\end{abstract}

Keywords :Microhydro; RETScreen Expert; Renewable energy; GHG emissions; Pakistan

\section{Introduction}

Industrial development, growing population, and expansion of urban areas have augmented the energy requirements in all divisions of Pakistan for the past two decades. Among the energy mix of Pakistan, $37 \%$ of the electricity is generated on imported oil carrying a major portion of the foreign payments to the oil rich countries [1,2]. The success of short term planning of the electricity generation to encounter the growing energy requirements has shifted the energy mix from hydro dominance to the thermal dominance as shown in Figure 1. Regrettably, in spite of having plentiful renewable energy sources, Pakistan is confronting a serious power deficit even in its on grid countryside and city zones. The topographical position of Pakistan creates a country prosperous in sustainable and renewable energy sources such as geothermal, solar PV, solar thermal, biomass, hydro, and wind. Bearing in mind the sustainable and green energy outlook, being an inexpensive, tidy, and ecosystem friendly resource of energy, hydro is the best solution of the prevailing conditions of electricity. Pakistan initiated exploiting the potential of hydro power since its presence. Corresponding to an assessment, $59 \mathrm{GW}$ potential of hydro power is available in Pakistan [2]. Table 1 classifies the types of turbines based on their applications and size of the hydro project. Small and micro hydro power are getting admiration in the world for remote/off grid hamlets, isolated and rough areas [3-5] which are yet out of the national flow of improvement. About 50million people in Pakistan are deprived of admission to the grid [6]. Erection of such hydro power system do not require a bigger water sink and storage. In these off grid regions, micro/mini hydro power locations are practicable results $[7,8]$ where the flowing water at a specific head of the canal or any adjacent water source is depleted to a nearby lake and thrown to the rotating turbine to transfer into electrical energy using a connected 
electrical alternator. The passing water in the tailrace after exhausting its potential through the turbine to the electrical generator can also be sent for adjacent agrarian lands and local determinations $[9,10]$ and directed to the conventional flow. Jawahar et al. [9] have introduced an assessment analysis on turbines of micro hydro power and, Haidar et al. [11] has categorized type of turbines regarding head as following:

1. Low head (40 m): Kaplan, Propeller

2. Medium head (40 to $100 \mathrm{~m}$ ): Cross Flow, Pelton wheel, Francis and Pump as turbine.

3. High head $(>100 \mathrm{~m})$ : Pelton Wheel and Turgo

Hofken [12] recommended the development of rural tenants' social and commercial life cycle in Pakistan by launching micro/mini hydro plants in far off countryside regions where latent potential is accessible and utilized the phrase "small is beautiful" for micro/mini hydropower. Vyaas et al. [13] performed a viability study for applying micro/mini hydropower in drylands of different states of India and determined it unsurpassed for self-adequacy in energy. Zeema et al. [14] assessed the technical and economical practicality of micro hydro power in the agrarian fields and discovered it lucrative in the Italian power marketplace. Kamran et al. [15] anticipated the designing and economic optimization of a micro hydro system on link canal of Balloki barrage and Sulamanki barrage. They designed the system for the proposed location, performed the sensitivity analysis of the hydro power and optimized the economics by using HOMER Pro.

The project is located at Sakhakot, Malakand agency, Khyber Pakhtunkhwah Province. The area belongs to the lesser Himalayas, Malakand Agency. In the current study project layout, capacity, water availability, area to be benefited and the needed infrastructure for the accomplishment of the project were assessed. The conducted study recommends a micro hydro power plant on Jalala Disty Canal (RD: 18+051) Sakhakot, Malakand taking a generous potential of electricity to gratify the energy requirements of the neighboring areas.

The paper is designed as: Section 1 comprises of an introduction and overview of the microhydro in Pakistan, section 2 deliberates the energy position of the Pakistan and discusses the prospects of hydro power potential available in the country at large and small capacity level. Section 3 illustrates the project location where the micro hydropower plant is projected. The designing of the anticipated micro hydro project has been discussed in Section 4. In section 5, cost estimation of the planned system is presented. Section 6 describes the RETScreen optimization of the system. Section 7 is the conclusion of the study.

\section{Energy scenario of Pakistan}

Pakistan's existing electricity condition is, regrettably, experiencing a serious shortfall of almost 5000 MW that has directed to a comprehensive blackout from nearly 13-17 hours a day [17-19]. The source-centered energy mixture of Pakistan (2008-16) is displayed in

Table 2. Existing energy blend of the countryside is thermal assertive taking the cost of electricity too high as the thermal operated power plants are normally conventional and imported fossil fuel based (37.5\% oil, $30.17 \%$ gas) in 2016 controlled by Private Power Producers. Percentage of the electricity generated from thermal sources since 2009 has been advanced than other conventional energy sources already in practice in Pakistan. Energy resources that replenish themselves like biomass, wind, solar, and hydro capacity are in profusion in Pakistan. Amongst the renewables, hydro power is the low-appraised one and environmentally outgoing. Pakistan is rich in water resources having a $59000 \mathrm{MW}$ workable micro, small and large hydro energy potential [2]. Successively bulky hydro power plants are Nelam-Jhelum (950MW), Tarbela (3478MW), Ghaazi Brootha (1450MW), Mengla (1000MW), Warsik (240MW), and Chshma (184MW) [20,21]. Apart from these, several hydro power projects, Kalabaagh (3600MW), Bhaasha (4500MW), Bunjji (5400MW), Dasoo (4000MW), Kohaala (1100MW), Thakoot (2800MW), Pataan (2800MW), Munnda (750MW) and Akhore (600MW) [22], are either at several stages of project expansion or in future lined up. For the unwarranted postponement in execution of the projects, hydro power possibly will not survive its development. The hydro percentage in the national electricity mix of the country has been condensed from $71 \%$ in 1961 [2] to $29 \%$ in
2016 [23]. Batool et al. [24] has debated the grounds for prolonging the hydro power ventures in the country. Micro hydro is the top alternate source of power for off grid communities to electrify the village. Such micro hydro power ventures can electrify the isolated areas from the electricity grid and adjacent the farming lands having irrigation channels with a high level head.

Table 1. Size based types of hydro power plants [16]

\begin{tabular}{|l|l|l|}
\hline $\begin{array}{l}\text { Sr. } \\
\text { No. }\end{array}$ & $\begin{array}{l}\text { Hydro power } \\
\text { plant type }\end{array}$ & Size assortment \\
\hline I & Pico & $<5 \mathrm{~kW}$ \\
\hline II & Micro & $5 \mathrm{~kW}-100 \mathrm{~kW}$ \\
\hline III & Mini & $101 \mathrm{~kW}-2 \mathrm{MW}$ \\
\hline IV & Small & $2001 \mathrm{~kW}-25 \mathrm{MW}$ \\
\hline V & Medium & $25001 \mathrm{~kW}-100 \mathrm{MW}$ \\
\hline VI & Large & $>100 \mathrm{MW}$ \\
\hline
\end{tabular}


The distant off grid societies from the national grid and close the agricultural lands and irrigation channels with an extraordinary head can be captivated by these micro hydro power ventures. Alternative Energy Development Board (AEDB) projected about $3100 \mathrm{MW}$ micro hydro power capacity projects at expected collapses and water canals in
Pakistan. Gilgit only has 1300 MW prospective at 200 sites. The administration of Kheber Pakhton Kha (KPK) finalized 87 micro hydro projects varying from $15 \mathrm{~kW}$ to $100 \mathrm{~kW}$ in distant and hard landscapes of KPK in 2016.

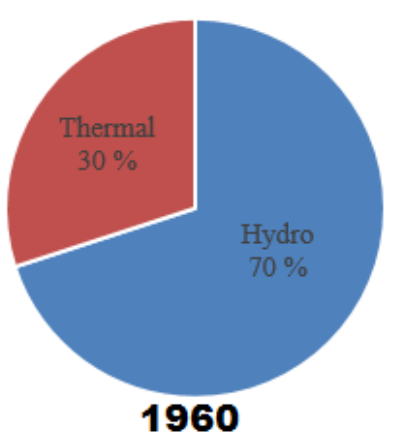

1960

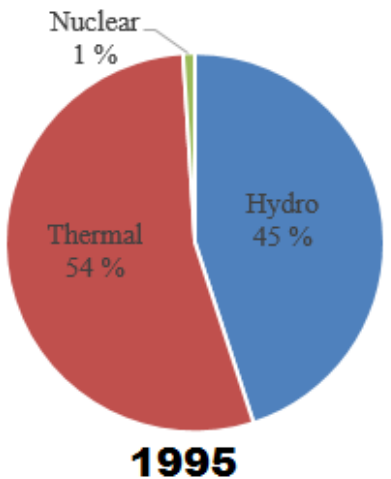

1995
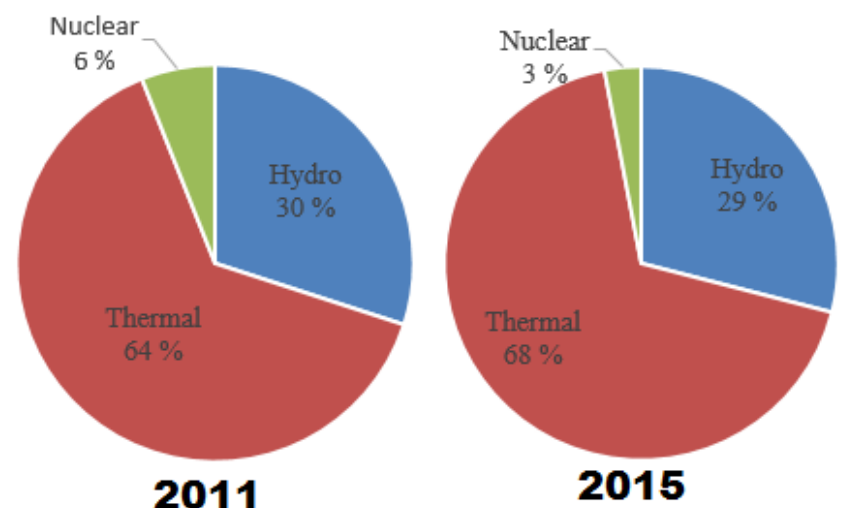

Figure 1: Transition of Energy Mix of Pakistan

Table 2. Energy mix of Pakistan $[23,25,26]$ in GW

\begin{tabular}{|l|l|l|l|l|l|l|l|l|}
\hline & $\mathbf{2 0 0 8}$ & $\mathbf{2 0 0 9}$ & $\mathbf{2 0 1 0}$ & $\mathbf{2 0 1 1}$ & $\mathbf{2 0 1 2}$ & $\mathbf{2 0 1 3}$ & $\mathbf{2 0 1 4}$ & $\mathbf{2 0 1 5}$ \\
\hline Thermal & 13.539 & 14.576 & 15.047 & 16.363 & 16.069 & 16.041 & 16.366 & 16.814 \\
\hline Wind & 0 & 0 & 0 & 0 & 0.001 & 0.50 & 0.106 & 0.106 \\
\hline Nuclear & 0.462 & 0.462 & 0.462 & 0.787 & 0.787 & 0.787 & 0.787 & 0.787 \\
\hline Hydro-electricity & 6.555 & 6.555 & 6.555 & 6.645 & 6.730 & 6.947 & 7.116 & 7.116 \\
\hline Installed capacity & 20.23 & 20.55 & 22.06 & 23.79 & 23.58 & 23.82 & 24.37 & 24.82 \\
\hline Peak supply & 12.44 & 13.63 & 12.75 & 13.19 & 12.32 & 14.60 & 16.17 & 16.50 \\
\hline Peak demand & 16.83 & 17.85 & 18.46 & 18.52 & 18.94 & 18.82 & 20.57 & 21.70 \\
\hline Deficit & $(4.39)$ & $(4.21)$ & $(5.71)$ & $(5.32)$ & $(6.62)$ & $(4.22)$ & $(4.40)$ & $(5.20)$ \\
\hline
\end{tabular}

Table 3. Pakistan micro-hydro power potential [27]

\begin{tabular}{|l|l|l|l|l|l|}
\hline $\begin{array}{l}\text { Sr. } \\
\text { No. }\end{array}$ & Area & $\begin{array}{l}\text { Potential } \\
\text { (MW) }\end{array}$ & $\begin{array}{l}\text { Number } \\
\text { of } \\
\text { potential } \\
\text { locations }\end{array}$ & $\begin{array}{l}\text { Total } \\
\text { available } \\
\text { potential } \\
\text { (MW) }\end{array}$ & Available location \\
\hline 1 & Gilgit & $0.1-38$ & 200 & 1300 & Natural falls \\
\hline 2 & Punjab & $0.2-40$ & 300 & 560 & Canals \\
\hline 3 & Sindh & $5-40$ & 150 & 120 & Canal falls \\
\hline 4 & Khyber Pakhtun Khawa (KPK) & $0.2-32$ & 125 & 750 & Micro based falls \\
\hline 5 & Azad Kashmir & $0.2-40$ & 40 & 280 & Natural falls \\
\hline & Total & & & $\mathbf{3 1 0 0}$ & \\
\hline
\end{tabular}

Table 4. Functioning micro hydro power stations [24]

\begin{tabular}{|l|l|l|}
\hline Power plant & Capacity (MW) & starting date \\
\hline Chicoki & 13.2 & 1959 \\
\hline Renala & 1.1 & 1925 \\
\hline Shadiwal & 13.5 & 1961 \\
\hline Rasul & 13.8 & 1952 \\
\hline Dargai & 20 & 1951 \\
\hline Nandipur & 13.8 & 1963 \\
\hline
\end{tabular}

Table 3 illustrates the hydro potential at micro level in various provinces of the country. Functioning small hydro power projects in Pakistan are comprehensively given in 
Table 4. Figure 1 shows the image of the scenario how the transition of energy mix took place from hydro dominant to thermal dominant.

\section{Project site description}

The project area is covered by a thick sequence of alluvium and shown in Figure 2 and is generally comprising of silt, clay, sand gravel and organic material. Hence the alluvium of project area comprises mostly of weathered material from schistose rocks. The soil of the project area is very fertile and is used for agriculture purposes.

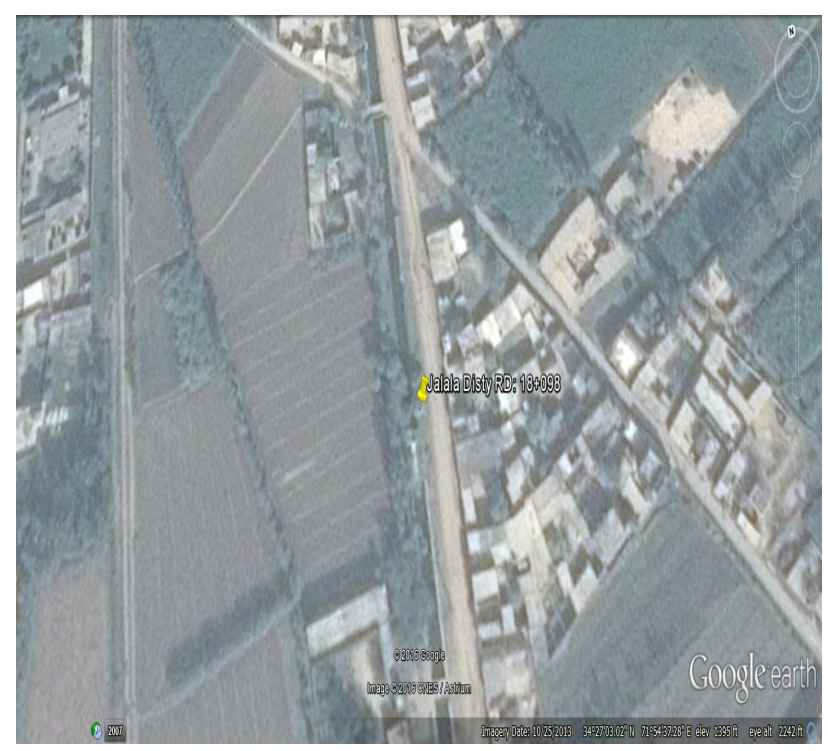

Figure 2: Satellite view of the project proposed location

For the feasibility level of the study of the proposed project, the geotechnical investigations conducted by Hydro Electric Planning Organization (HEPO) have been used as a reference. The geotechnical investigations carried out by HEPO are in the vicinity of proposed project and therefore may be utilized for the Savvy Links Machai Hydro power Project. However, for detailed engineering design, it is recommended that the following geotechnical investigations may be carried. The general geology of the project area is shown in Figure 3.

\section{Designing of micro hydro system}

\subsection{Resource assessment}

The flow rate data was measured at the proposed location and accordingly a flow duration curve format was developed by the flow rate shown in table 5 . Using the data of the table 5 , flow duration curve was drawn as discussed in section 4.2.1.

\subsection{Flow duration curve}

Flow Duration Curve is a method of establishing the expulsion information of a flow at a water channel in a curve look that presents an approximation of the portion of the period at which the flow rate matches or surpasses some value of concern. FDC is gained by organizing the flow percentage and sketching it on the y-axis at equivalent periods of proportion on the x-axis. To well introduce the expulsion performance with higher precision, daily time step dimensions are required to get FDCs [30]. Though, FDCs is plotted for a particular time period and for any specific year. The collected data of discharge are represented in \% of the time and is presented in table 4.3 and plotted in Figure. The annual closer period for the canal is the same as that for the other canal, i.e. the month of January. However. From the data collected it was observed that in the flow was recorded for some years in the past due to the availability of water at the head regulator. But in the current project, the calculation for the month of January is neglected and is considered zero discharge value for the calculation of power and energy.

The collected data was analyzed, and it was found that the minimum discharge of $73 \mathrm{ft}^{3} / \mathrm{s}$ is available for $75 \%$ of the time. However, the maximum discharge of $132 \mathrm{ft}^{3} / \mathrm{s}$ is available for approximately $8.33 \%$ as shown in Figure 4 .

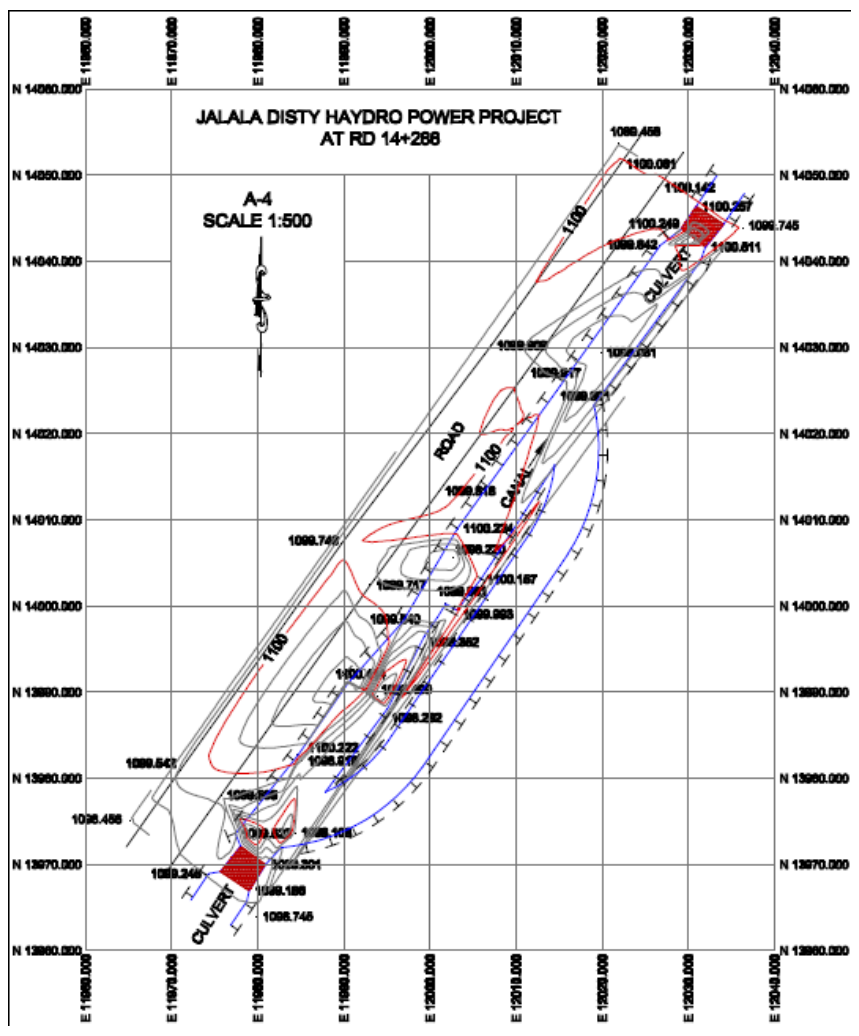

Figure 3: General geology of the project area

Various outlets were taken from the main canal between the head regulator and the proposed project site. But the data presented in the above tables were taken at the project site 
and therefore, no need for subtracting the outlets' data form Discharge at head regulator $=73 \mathrm{ft}^{3} / \mathrm{s}=2 \mathrm{~m}^{3} / \mathrm{s}$ the calculated discharge levels. Hence, the design discharge at the project site is $73 \mathrm{ft}^{3} / \mathrm{s}$.

The detail of discharge calculation at the project site is carried out below:

Table 5: Availability of discharge at the head regulator in $\%$ of the time.

\begin{tabular}{|c|c|c|c|}
\hline \% Time Flow Exceeded & $\begin{array}{c}\text { Percentile } \\
\text { (Flow rate) }\end{array}$ & \% Time Flow Exceeded & $\begin{array}{c}\text { Percentile } \\
\text { (Flow rate) }\end{array}$ \\
\hline 8.33 & $\mathbf{1 3 2 . 5}$ & 58.33 & $\mathbf{8 9}$ \\
\hline 16.66 & $\mathbf{1 3 2 . 5}$ & 66.66 & $\mathbf{7 6}$ \\
\hline 25 & $\mathbf{1 2 8 . 5}$ & 75 & $\mathbf{7 3}$ \\
\hline 33.33 & $\mathbf{1 0 8 . 5}$ & 83.33 & $\mathbf{7 3}$ \\
\hline 41.66 & $\mathbf{1 0 0}$ & 91.66 & $\mathbf{5 9 . 5}$ \\
\hline 50 & $\mathbf{9 8 . 5}$ & \multicolumn{2}{c|}{$\begin{array}{c}\text { weir height } \\
\text { weir width }\end{array}$} \\
\hline
\end{tabular}

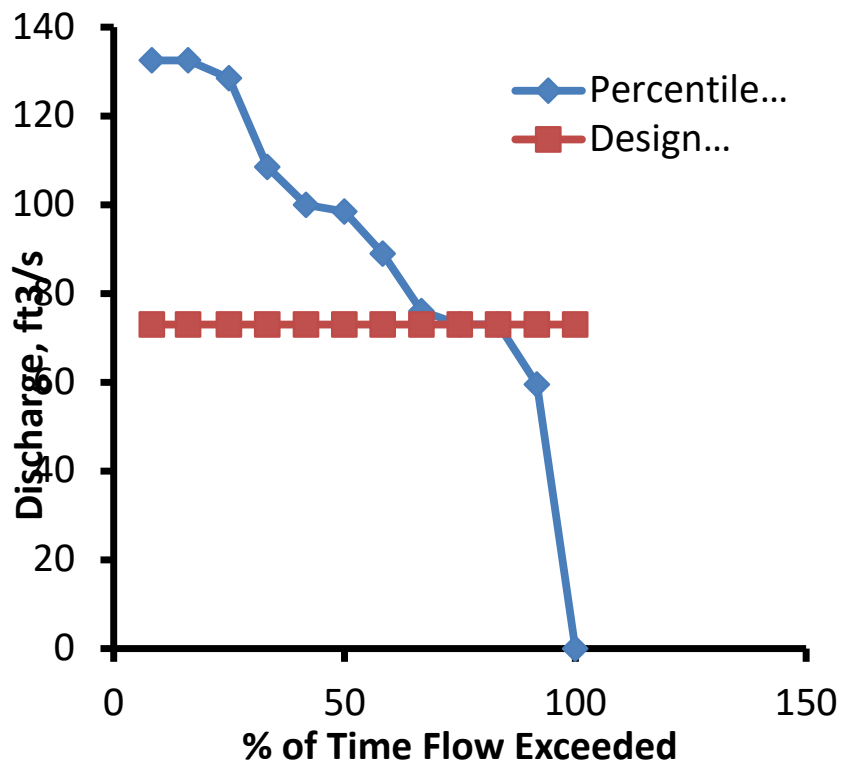

Figure 4: Flow duration curve and the designed flow rate

\subsection{Weir and open channel}

A weir/barrage exhibits a fence crossway the water flow specifically expected to alter the water flood features. Hydrologists utilize the barrier to gauge the volumetric stream proportion in moderate and minor waterways. Typically, it is a small fence or a small dam with a cut to drain the water. The emission of water can be designed by simply determining the level divergence amid the higher flow of water and the inferior side of the channel. Considering the type of the material and the structure, several types of trenches are employed such as Vee, trapezoidal, and rectangular invented of metal and wood. Eq. (i) [31] is utilized to determine the water flow-rate at the nick.

$$
Q=(1.8) \times(W-0.2 h) \times h^{3 / 2} \quad\left(m^{3} / s\right)
$$

Nasir [31] explained by constructing the height and the width of barrage in a one ratio three (1:3) proportion, aspects of the barrage, and the water flow can be determined. In the proposed investigation it is $5.040 \mathrm{~m}^{3} / \mathrm{s}$.

Robert Manning, in 1890, presented equation (ii) substitute to the Chezy equation that oversees the open channel flowrate. Equation (ii) is associated with the consistent open channel flow and is presented in Eq. (ii) [31].

$Q=\frac{1}{n}\left(s . f \times s^{1 / 2}\right)\left(m^{2} / s\right)$

s.f section factor $=A R^{2 / 3}$

$n$ Gauckler-Manning coarseness coefficient (material dependent)

$S$ channel's bottom line slope

Eq. (ii) is updated to Eq. (iii) that determines the channel's lowest slope.

$S=\left(\frac{Q \times n}{A \times R^{2}}\right)^{2}$

To compute the slope of the bottom-line, we prerequisite to compute the hydraulic radius $(R)$ of the crosssectional area and the cross-sectional area of the open channel by using Eq. (iv) and Eq. (v) respectively.

$R=\frac{A}{p}=\frac{A}{W+2 h}$

$A=W \times h$ 
$P \quad$ perimeter of the rectangular channel

A Cross-sectional area of open channel

By using all the identified parameters in Eq. (iii), bottom line slope of the canal can be designed that shows an even drift. The flow rate in the open channel is $5.040 \mathrm{~m}^{2} / \mathrm{s}$ by using the Gauckler-Manning equation (ii). Whereas, the velocity in the open channel is determined by Eq. (iv) [32]. The velocity of the water in the open channel is $\left(1.68 \frac{\mathrm{m}}{\mathrm{g}}\right)$ determined by the equation (iv).

$V=\frac{Q}{A}$

\subsection{Trash Rack Designing}

The obstacles that face the flow to stop the movement and submerged fragments from receiving into the opening and destructing penstock, and the turbine are known as the trash rack [33]. Slabs of explicit thickness with specific arrangement are positioned at a leaning of $61^{0}$ to $81^{0}$ at horizontal-axis. Nasir et al. [31] has described some distinctive standards of the bar space for diverse types of turbines ( 80 to $100 \mathrm{~mm}$ for Kaplan turbines, 20 to $30 \mathrm{~mm}$ for Pelton, 40 to $50 \mathrm{~mm}$ for Francis turbine). The fragments accrued in the trash rack are required to be detached frequently either physically or by some methodical technique, or else, they can create some additional head losses.

\subsection{Penstock design}

Penstock is used to conduct the flowing water in weir to the open channel and then from head to the turbine. Penstock design is much important regarding its diameter, thickness, material, and cross-sectional area. Penstock is important in way as it is the main part where the energy of falling water is converted from potential energy to the kinetic energy of the moving water and hence moving the generator coupled turbine. Because of numerous aspects like the ambient temperature, penstock material, ground nature, ambient temperature, and environmental factors, it could be either visible or hidden below the ground.

\subsection{Penstock diameter}

Eq. (vii) [31] can be used to to determine the diameter (internal) of the penstock.

$$
D=(2.690) \times\left(n^{2} \times Q^{2} \times \frac{L}{H_{g}}\right)^{0.1875}
$$

\footnotetext{
n Gauckler-Manning coefficient (0.011 for PVC)

D internal diameter of the penstock

$L \quad$ penstock length
}

$$
\begin{array}{ll}
Q & \text { design flow } \\
H_{g} & \text { gross head }
\end{array}
$$

The internal penstock diameter for the conducted study is $650 \mathrm{~mm}$ using equation (vii).

\subsection{Penstock thickness}

The stiffness of the wall of the penstock is dependent on the operating pressure, penstock material and diameter, and the ductile strength. Eq. (viii) [31] presents the least stiffness of the penstock.

$t=\left(\frac{D+509}{400}\right)+1.2(\mathrm{~mm})$

t $\quad$ minimum penstock wall thickness $(\mathrm{mm})$

Penstock thickness is $4.095 \mathrm{~mm}$ using eq. (viii).

\subsection{Penstock Cross sectional area}

$$
A=\frac{\pi D^{2}}{4}\left(m^{2}\right)
$$

$D \quad$ penstock diameter $(m)$

A penstock area of the cross section

Equation (ix) gives the penstock cross sectional area as 0.33 $\mathrm{m}^{2}$.

\subsection{Velocity through the penstock}

$$
V=\frac{Q}{A} \quad(6.26 \mathrm{~m} / \mathrm{s})
$$

\subsection{Head friction losses}

While measuring the available power in the water, head/penstock losses must be considered. These are the sufferers happening because of the roughness of the water to the wall of the penstock and may be determined by Eq. (xi) [34].

$$
h_{f}=f \times\left(L_{D}\right) \times \frac{V^{2}}{2 g} \quad(m)
$$

$$
\begin{array}{ll}
f & \text { friction factor }(0.017 \text { using eq. } 12) \\
v & \text { average velocity }(\mathrm{m} / \mathrm{s}) \\
D & \text { penstock diameter }(\mathrm{m}) \\
L & \text { penstock length }(\mathrm{m}) \\
g & \text { acceleration due to gravity }\left(9.8 \mathrm{~m} / \mathrm{s}^{2}\right)
\end{array}
$$

The friction factor can be determined by eq. (12) [34].

$$
f=124.5 \times \frac{n^{2}}{D^{19}}
$$


By using the above stated numerical values in Eq. (xi), head friction losses can be determined and it is $0.51 \mathrm{~m}$.

\subsection{Inlet losses}

$h_{\mathrm{i}}=f_{\theta} \times \frac{V^{2}}{2 g} \quad(m)$

$h_{\mathfrak{i}} \quad$ the inlet losses

$f_{e} \quad$ the inlet coefficient, ( 0.5 for microhydro)

By using Eq. (xvii), hypothetical power without considering the efficiency of the system comes out in $\mathrm{kW}$.

\subsection{Turbine power}

After considering all the power losses like penstock friction losses, valve losses, and inlet losses, and turbine efficiency, the power that a turbine can provide to the generator can be determined by using Eq. (xviii).

$P_{\text {acto }}=\rho g Q H_{n} \eta(W)$

Eq. (xiii) gives inlet loss as $0.98 \mathrm{~m}$.

\subsection{Valve losses}

$h_{D}=f_{D} \times \frac{V^{2}}{2 g} \quad(m)$

$f_{D} \quad$ valve type coefficient ( 0.1 for the butterfly valve)

$h_{D} \quad$ the valve losses

Eq. (xiv) gives valve losses as $0.196 \mathrm{~m}$.

Total losses can be determined by adding all the losses given by Eq. (xv).

$$
\begin{array}{ll}
\eta & \text { system efficiency }(75 \%) \\
H_{n} & \text { net head }(m)
\end{array}
$$

The actual electric power that the system can deliver is in $k W$.

\subsection{Speed of the Turbine}

Capacity factor $(\sigma)$ governs the turbine type appropriate for the project location and if the water flow rate, turbine speed, and the head are recognized, it can be determined by the eq. (xix) [36]. Conversely, the capacity factor can be assessed if the head is known by the graph as shown in

$\sigma=\frac{2 N \sqrt{\pi Q}}{(2 g H)^{3 P_{4}}}$

$$
H L=h_{f}+h_{i}+h_{E} \quad(1.686 m)
$$

Net Head $=$ Gross Head - Head losses

(m) (xvi)

Eq. (xvi) can be used to determine the net head. Net head is the head that is available after bearing all the losses and in the present case it comes out to be $8.3 \mathrm{~m}$.

\subsection{Hydro power}

Micro hydro produces electricity using a generator coupled to the turbine by taking the potential energy of dwindling water that is thrown on the turbine. Micro hydro does not need any main construction work, thus having no ecological belongings. Water from the runing canal/river/natural fall is abstracted and after generating electricity diverted to the mainstream. The power of generating electricity in water is dependent upon head of the dwindling water and flow rate and that can be determined by the eq. (xvii) [35].

$$
P_{\mathrm{t}}=\rho g Q H_{g}
$$

$\rho \quad$ water density $\left(1000 \mathrm{~kg} / \mathrm{m}^{3}\right)$

$H_{g} \quad$ gross head $(m)$

g gravitational acceleration $\left(9.8 \mathrm{~m} / \mathrm{s}^{2}\right)$

$P_{\mathrm{t}} \quad$ theoretically available power $(W)$

$Q \quad$ flow rate $\left(\mathrm{m}^{3} / \mathrm{s}\right)$
N $\quad$ speed of the turbine in r.p.m.

$\sigma \quad$ characteristic factor of the turbine

$H \quad$ net head $(m)$

$Q \quad$ design flow $\left(\mathrm{m}^{3} / \mathrm{s}\right)$

$g$ gravitational acceleration of dwindling water $\left(9.8 \mathrm{~m} / \mathrm{s}^{2}\right)$

Eq. (xix) can be reordered to Eq. (xx) $[36,37]$ to discover the rotating speed of the turbine. The characteristic factor $(\sigma)$ of the turbine is created from Error! Reference source not found..

$N=\frac{\sigma(2 g H)^{3 \mathbb{N}_{4}}}{2 \sqrt{\pi Q}} \quad$ (r.p.m.)

The turbine specific-speed can be determined by using Eq. (xxi) [32,36,38].

$N_{Q}=\frac{N_{\sqrt{Q}}}{H^{3 / 4}}$

(r.p.m.)

\subsection{Turbine selection and design}

After calculating the net head, the characteristic factor and the type of the turbine is read from the graph Error! Reference source not found.. If the head is greater than $50 \mathrm{~m}$, Pelton turbines are preferred. Francis turbines are applied where the head range is between $10 m-50 m$, whereas, for the head beneath $10 \mathrm{~m}$, Kaplan turbines are used [39]. Considering the interpretation from Error! Reference source not found., kaplan turbine is selected for the 
recommended system. However, the capital cost of the Kaplan turbine is much higher compared to the design and manufacturing of water wheel. Similarly, the manufacturing of water wheel required less expertise compared to Kaplan Turbine. Similarly, the water wheel is recommended for low head as discussed above. Based on these arguments, the breast shot water wheel was selected to produce electricity at the project site.

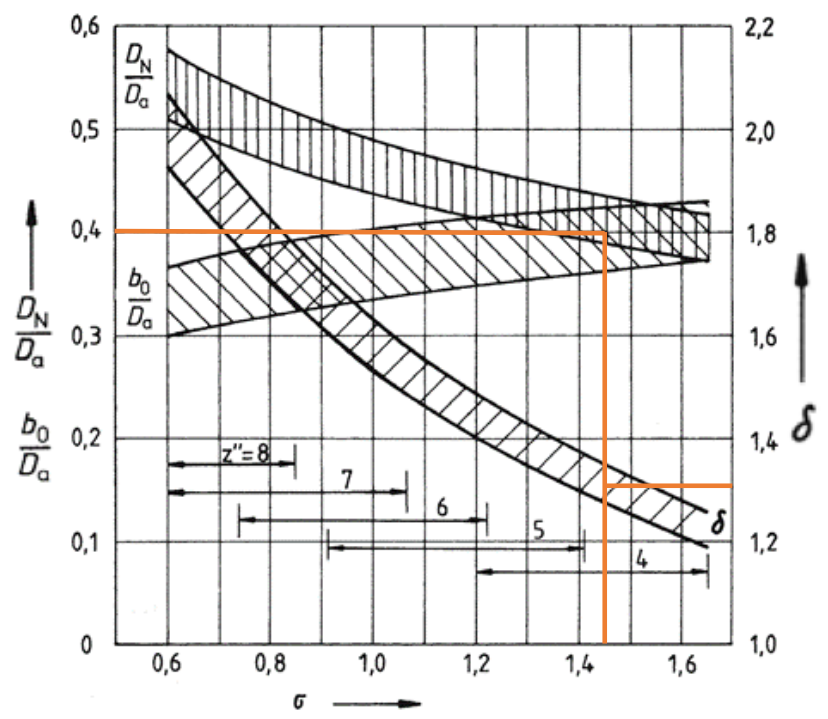

Figure 5: Design parameters of a Kaplan turbine

When the turbine type is recognized, other parameters of the turbine can be determined. Outer and inner diameter of the wheel, and the ratio $\frac{D_{N}}{D_{\mathrm{In}}}$ are calculated by using Eq. (xxii), Eq.(xxiii) and Eq.(xxiv) respectively [37].

$D_{a}=\frac{26}{\pi} \times \sqrt[4]{\frac{Q^{2}}{2 g H}}$

$D_{\ltimes} \quad$ hub inner diameter

$\delta \quad$ diameter number

$D_{N}=4 D_{\alpha}$

$D_{\mathrm{N}} \quad$ turbine outer diameter

The $2 \mathrm{~cm}$ thick sheet was used to cut discs of $3.2 \mathrm{~m}$ in external diameter and internal diameter of $2.57 \mathrm{~m}$. These discs were cut using the sheet metal cutting machine. The measurement was taken using the measuring tape. The reading was taken in such a way that the tape one end was put at the center of the sheet and circle was drawn on the sheet having an external diameter of $3.2 \mathrm{~m}$ and internal diameter of $2.57 \mathrm{~m}$ as shown in Figure 6 . The number of buckets use in the wheel is decided based on the circumference of the wheel. As per calculation of the circumference of the water wheel, one bucket at one foot was decided to be used in the final assembly. The total number of buckets to be used in the fabrication of the breast shot water wheel was 33 . The positioning of the bucket was achieved by dividing the discs into 33 equal divisions as shown in Figure 7.

A cylinder made of mild sheet having thickness of $2 \mathrm{~cm}$ and diameter of $2.57 \mathrm{~m}$ is welded to the discs to make the base face of the buckets.

The shroud of the wheel cutter in above form a metallic sheet having an internal diameter of $2.57 \mathrm{~m}$ and external diameter of $3.2 \mathrm{~m}$ and welded to the discs to form the sides of the buckets used in the fabrication of breasts hot water wheel. For checking of the cracks and holes, water test of the shroud joints was done and made sure that there should be no leakages of water during operation of the water wheel.

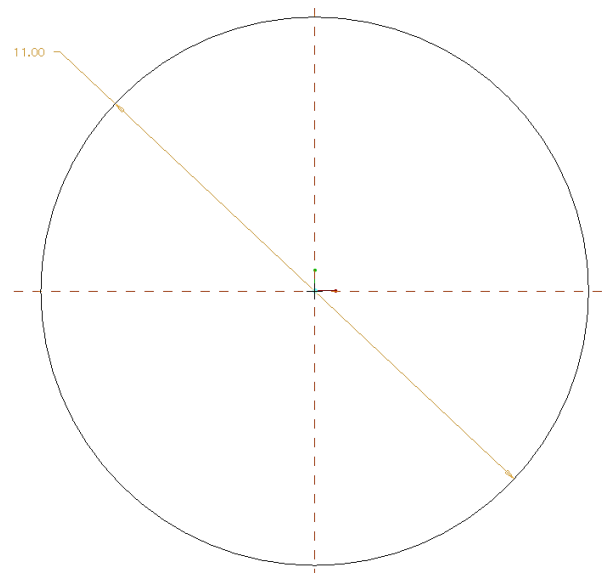

Figure 6: Water wheel discs dimension

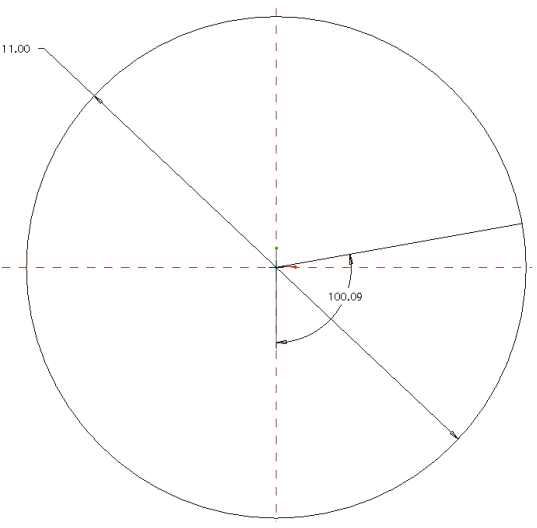

Figure 7: Buckets position on the wheel circumference

A shapper machine and welding process was used to make the buckets for the water wheel. A total of 33 buckets was made for the water wheel and was welded to the shroud of the water as shown in Figure 8. 


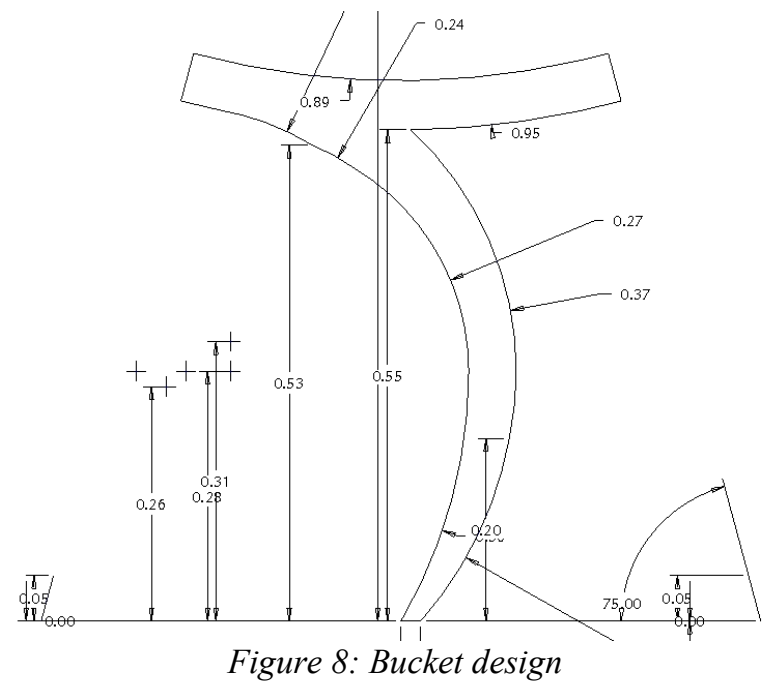

Generally, it is difficult to fabricate a new bearing for the current project due to cost and infrastructure available, however, based on the available information, $4 \mathrm{~cm}$ bore pillow block self-lube bearings was selected for mounting the shaft of the water wheel. Proper lubrication and maintenance of the bearing will be ensured using the standard operating procedure provided by the supplier.

$>$ Some advantages in using lubricated bearings are that they:

$>$ Avoid severe erosion of the shaft and bearing materials

$>$ Can be refurbished or substituted.

$>$ Can deliver a transitory solution to the renovation

A $10 \mathrm{ft}$ long shaft was selected for the main supporting shaft of the water wheel. The shaft is mounted in bearing and is attached to the shroud of the water wheel through a metallic link welded at both ends. The metallic supports were provided to the shroud at three locations both at the extreme side of the wheel and at center location. The selected metallic links were designed to support the total weight of the water and wheel.

\section{Cost estimation}

The project cost estimate has been established on the basis of the current survey of the proposed project.

The cost of the project is divided into the following three sections:

$>$ Preliminary Work

$>$ Civil Work

$>$ Electromechanical Work

The construction cost of the project covers all civil work associated with the project including the transportation charges, investigation charges, planning cost, engineering and administration charges. A contingency charge is also included in the cost estimation of the project as a separate item to allow surplus amount of money to cover any differences in the cost during the project completion period.
The contingency charges were taken as $10 \%$ of the total amount of the project. The cost assessment is constructed on the following supposition that a single supplier will take total duty for the project accomplishment involving design and engineering, equipment purchasing, construction, , testing and installation.

\section{Components and cost estimation}

\subsection{Preliminary Work}

Preliminary cost of the project included the land and environmental cost. The following cost have been included:

$>$ Land acquisition

$>$ Providing necessary equipment and facilities

$>$ Security and other expanses

$>$ Providing transport between the camp and construction site

$>$ Workshop, warehouses, sheds and yards

$>$ Providing the maintenance vehicles for construction

$>$ Site investigation

$>$ Mobilization and demobilization of human resource and equipment

\subsection{Civil Works}

The civil works includes the cost of the following activities.

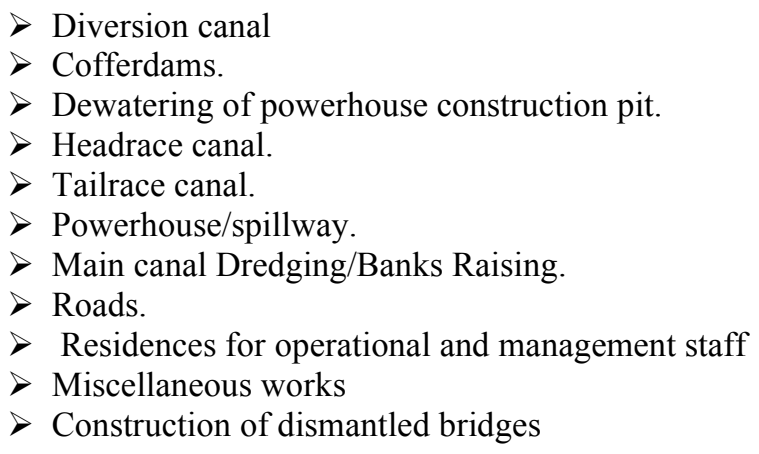

\subsection{Hydro and Electro-Mechanical Equipment.}

The cost of Hydro and Electro- Mechanical equipment includes the costs of equipment their transportation to the site and erection. The costs of the following items have been considered in the estimates.

$>$ Turbine and generator.

$>$ Mechanical equipment.

$>$ Electrical equipment.

\subsection{Other Costs.}

The other cost of the project includes:
$>$ Grid interconnection cost
$>$ Interest during construction
$>$ Insurances
$>$ Front end bank charges
$>$ Cost for financial and legal expertise 
$>$ Engineering \supervision and management cost

$>$ Administration audits and accounts

$>$ Import duties

$>$ Contingencies/ unforeseen.

\section{RETScreen Expert Optimization}

\subsection{Climate data}

RETScreen Clean Energy Management software is a software package developed and introduced by the government of Canada in 2016. The software can simulate the renewable energy systems either as an independent energy system or in integration with other renewable energy resources. It could be either a microgrid or a grid-connected renewable energy system. RETScreen Expert takes the coordinates of the location where the project is to be implemented and takes the environmental data like the air temperature, wind speed, relative humidity, precipitation, daily solar irradiance, earth temperature, and the atmospheric pressure. Figure 9 shows the weather data at the coordinates of the location where the micro hydro project is intended.

Month
January
February
March
April
May
June
July
August
September
October
November
December
Annual

\begin{tabular}{|c|c|c|c|c|c|c|}
\hline Air temperature & Relative humidity & Precipitation & $\begin{array}{l}\text { Daily solar } \\
\text { radiation - } \\
\text { horizontal }\end{array}$ & $\begin{array}{l}\text { Atmospheric } \\
\text { pressure }\end{array}$ & Wind speed & Earth temperature \\
\hline${ }^{\circ} \mathrm{C}$ & $\%$ & $\mathrm{~mm} \quad$ & $\mathrm{kWh} / \mathrm{m}^{2} / \mathrm{d} \quad$ & $\mathrm{kPa} \quad$ & $\mathrm{m} / \mathrm{s}$ & ${ }^{\circ} \mathrm{C}$ \\
\hline 9.7 & $44.1 \%$ & 27.90 & 3.08 & 93.7 & 1.7 & 7.6 \\
\hline 11.5 & $48.7 \%$ & 65.24 & 3.77 & 93.5 & 1.8 & 10.2 \\
\hline 16.8 & $46.4 \%$ & 67.58 & 4.76 & 93.3 & 1.9 & 16.0 \\
\hline 22.8 & $39.7 \%$ & 48.90 & 6.18 & 93.0 & 2.0 & 22.6 \\
\hline 29.1 & $27.0 \%$ & 24.18 & 7.31 & 92.6 & 2.1 & 29.7 \\
\hline 33.4 & $23.9 \%$ & 26.70 & 7.88 & 92.1 & 2.1 & 34.9 \\
\hline 32.7 & $41.2 \%$ & 75.64 & 6.96 & 92.1 & 2.4 & 34.7 \\
\hline 30.7 & $50.4 \%$ & 78.12 & 6.21 & 92.3 & 2.2 & 32.1 \\
\hline 28.0 & $41.5 \%$ & 35.70 & 5.87 & 92.7 & 1.9 & 28.5 \\
\hline 22.5 & $30.7 \%$ & 20.46 & 5.02 & 93.3 & 1.8 & 21.4 \\
\hline 16.9 & $29.9 \%$ & 15.30 & 3.76 & 93.6 & 1.7 & 14.5 \\
\hline 12.0 & $37.3 \%$ & 23.56 & 2.86 & 93.7 & 1.6 & 9.3 \\
\hline 22.2 & $38.4 \%$ & 509.28 & 5.31 & 93.0 & 1.9 & 21.9 \\
\hline
\end{tabular}

Figure 9: Environmental data of the proposed location

\subsection{RETScreen Technical Data}

The designed micro hydro system was modeled in RETScreen Expert using the information regarding resource assessment, hydro turbine and the losses given in the table.

Table 6: characteristics parameters of hydro resources and turbine

\begin{tabular}{|c|c|}
\hline \multicolumn{2}{|l|}{ Resource Assessment } \\
\hline Proposed Project & Run-off-river \\
\hline Gross Head & $10 \mathrm{~m}$ \\
\hline Maximum tailwater effect & $0.5 \mathrm{~m}$ \\
\hline Residual flow & $0 \%$ \\
\hline Firm Flow & $1.7 \mathrm{~m}^{3} / \mathrm{s}$ \\
\hline Firm Flow available & $9.5 \%$ \\
\hline \multicolumn{2}{|l|}{ Hydro turbine } \\
\hline Design flow & $2 \mathrm{~m}^{3} / \mathrm{s}$ \\
\hline Type & Kaplan \\
\hline Turbine efficiency & Standard \\
\hline Design Coefficient & 4.5 \\
\hline Turbine peak efficiency & $89 \%$ \\
\hline Flow at peak efficiency & $1.5 \mathrm{~m}^{3} / \mathrm{s}$ \\
\hline Turbine efficiency at design flow & $88.6 \%$ \\
\hline \multicolumn{2}{|l|}{ Losses } \\
\hline Maximum hydraulic losses & $16 \%$ \\
\hline Miscellaneous losses & $2 \%$ \\
\hline Generator efficiency & $75 \%$ \\
\hline Availability & $96 \%$ \\
\hline
\end{tabular}

\subsection{Turbine efficiency and power curve}

A graph or the efficiency curve of the no. of turbines used is shown in Figure 10. The efficiency of the turbine has been displayed against the percentage of the rated flow. The efficiency curve of the turbine indicates that the peak efficiency of the turbine is $89 \%$ if the flow of the water is $1.5 \mathrm{~m}^{3} / \mathrm{s}$. Between 30 and $100 \%$ of the rated flow, the efficiency is $88 \%$.

RETScreen Expert takes the flow data at the percentage exceedance and models the proposed micro hydro energy system at the designed flow rate noting the percentage of the time the flow rate is available. Figure 11shows the flow duration curve and the corresponding power curve at the corresponding percentage exceedance. It can be estimated from the figure that the maximum power $107 \mathrm{MW}$ is available at the designed flow rate of $2 \mathrm{~m}^{3} / \mathrm{s}$ that is available $85 \%$ time of the year. The efficiency of the turbine at the designed flow rate is $88.6 \%$ which is only $0.4 \%$ less than the maximum efficiency of the turbine. On the other hand, the available power changes as the flow rate are changed.

\subsection{Cost Summary}

All the costs discussed in section 5 were included in the initial investment in the RETScreen Expert that took all the technical and the economic parameters and performed the techno-economic feasibility of the proposed microhydro system. The project is to be constructed on a $70 \%$ debt ratio at $7 \%$ debt interest rate for a period of 15 years. The table shows the annual revenue and the financial feasibility of the 
project. The project is expected to generate $849 \mathrm{MWh}$ of electricity throughout its lifetime of 20 years which if sold to the consumers would generate an electricity export revenue of $50,917 \$$. The cost of the energy production was 0.049 $\$ / \mathrm{kWh}$ which saves an annual life cycle savings of 17,490 $\$$ yr. The Net Present Value (NPV) of the project is 139,280 $\$$ and the project is anticipated to recoup all the acquired costs in 3.1 years. The positive value of the NPV, Annual life cycle savings and the payback period confirm the viability of the project.

The RETScreen Expert determines the pre-tax internal rate of return (IRR) on the equity (\%), which characterizes the true interest return given by the project equity throughout its life prior to paying income tax. It is computed utilizing the pretax yearly cash flows (inflows and outflows) and the project life. It is also denoted as the return on equity (ROE) or return on investment (ROI) or the time-adjusted rate of return. IRR is that interest rate at which the NPV of all the cash inflows and outflows of the project are equal to zero.

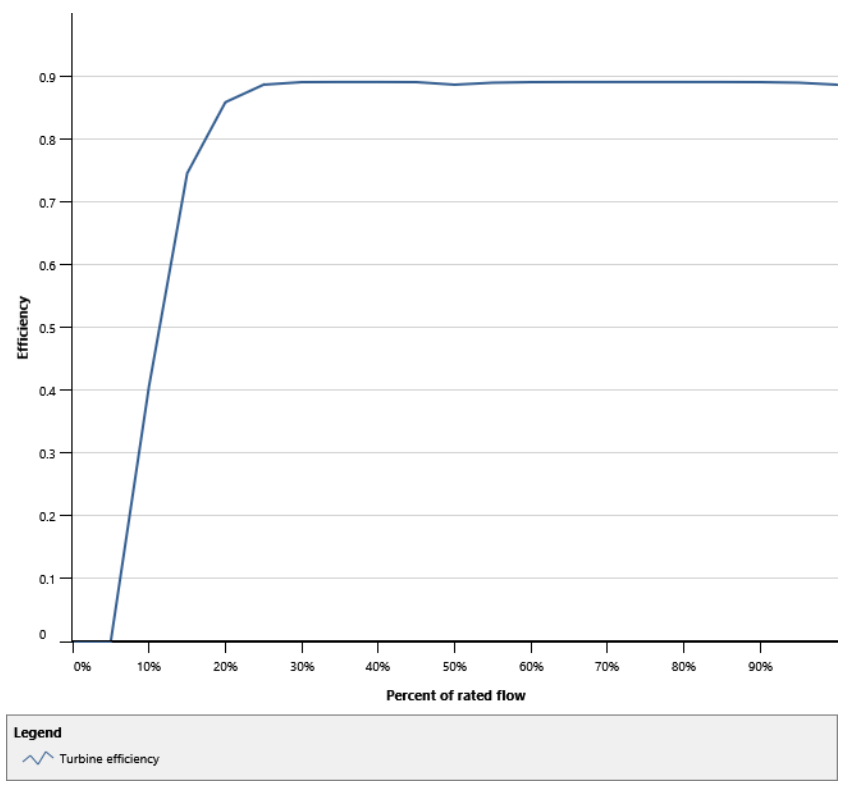

Figure 10: Turbine efficiency curve

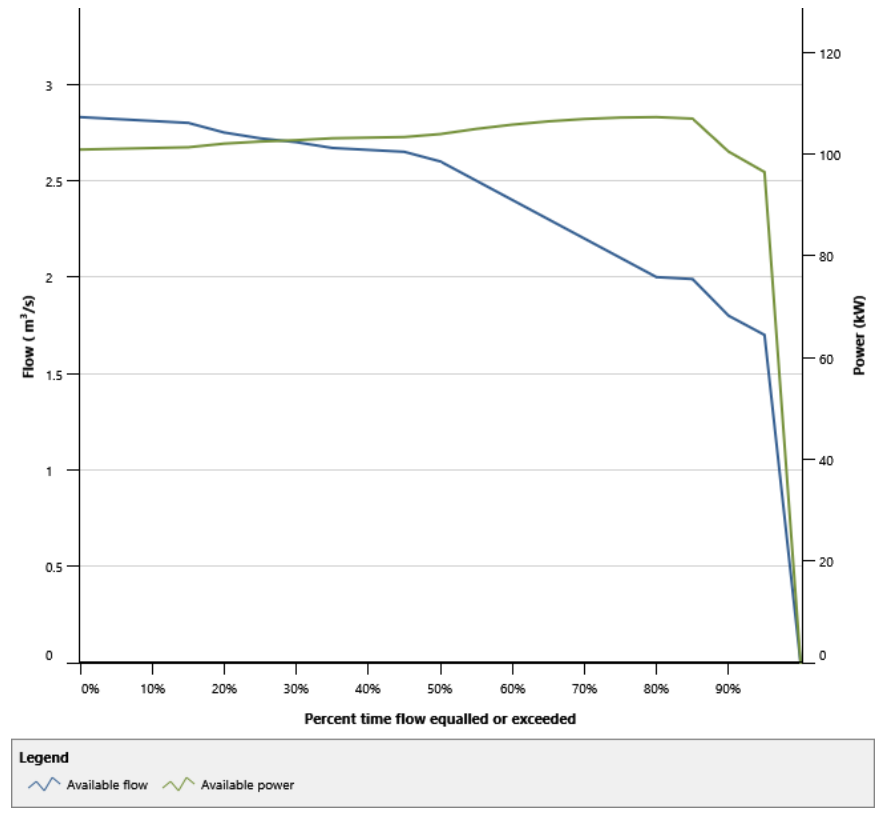

Figure 11: Flow duration and power curve

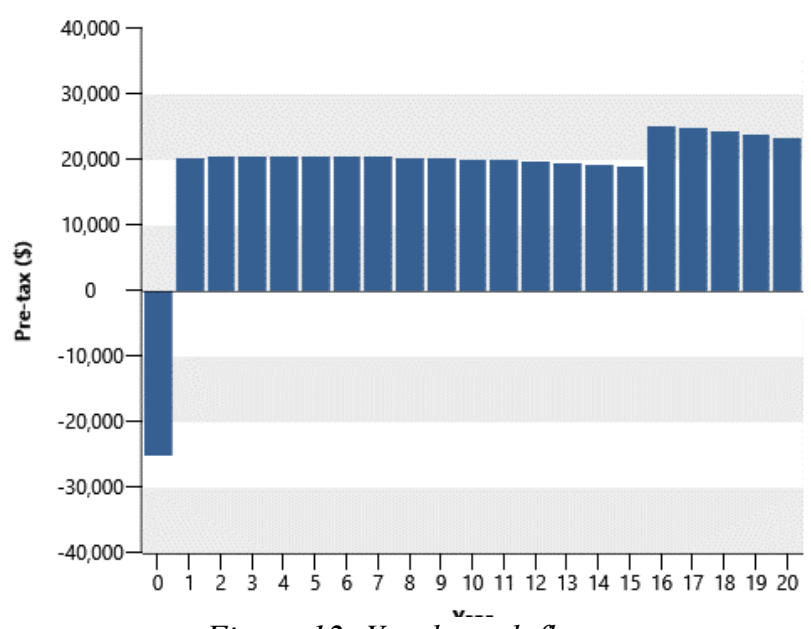

Figure 12: Yearly cash flow

Table 7: Cost summary of the project

\begin{tabular}{|l|l|}
\hline \multicolumn{2}{|l|}{ Annual revenue } \\
\hline & $849 \mathrm{MWh}$ \\
\hline Electricity exported & $50,917 \$$ \\
\hline Electricity export-revenue & $0.06 \$ / \mathrm{kWh}$ \\
\hline Electricity export-rate & \\
\hline \multicolumn{2}{|l|}{} \\
\hline Electricity export-escalation rate & $2 \%$ \\
\hline Gross GHG-reduction & $434 \mathrm{tCO}_{2} / \mathrm{yr}$ \\
\hline Gross GHG-reduction $(20 \mathrm{yr})$ & $8,673 \mathrm{tCO}_{2}$ \\
\hline GHG reduction revenue & 0 \\
\hline Financial viability & $81 \%$ \\
\hline Pre-tax IRR-(equity) & $20.6 \%$ \\
\hline Pre-tax MIRR-(equity) & $24 \%$ \\
\hline Pre-tax IRR-(assets) & $13.5 \%$ \\
\hline Pre-tax IRR-(assets) & $3.1 \mathrm{yr}$ \\
\hline Simple payback period & $139,280 \$$ \\
\hline Net Present Value (NPV) & $17,490 \$ / \mathrm{yr}$ \\
\hline Annual life cycle savings &
\end{tabular}




\begin{tabular}{|l|l|}
\hline GHG reduction cost & $-40.33 \$ / \mathrm{tCO}_{2}$ \\
\hline Energy production cost & $0.049 \$ / \mathrm{kWh}$ \\
\hline
\end{tabular}

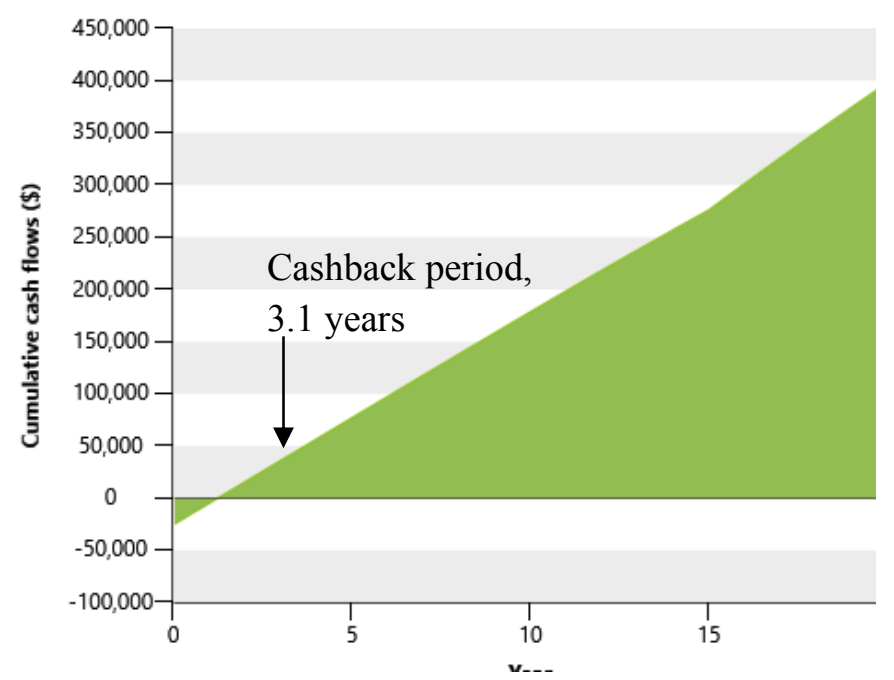

Figure 13: Yearly cumulative cash flow

RETScreen Expert takes the O\&M savings, Fuel savings, Periodic savings, production credits, incentives, and GHG credits as the cash inflows whereas the equity investment, O\&M payments, annual debt payments, and periodic costs as the cash outflows. In the proposed project, in Pakistan there are no carbon credits on the GHG emission reduction, and no incentives on renewable energy projects. Figure 12 shows the yearly cash flows of the project. In the $1^{\text {st }}$ year there is only equity investment as cash outflow. Subsequently there is annual electricity export revenue after paying the debt payment of $6458.14 \$ / y r$ as shown in Figure 12. After $15^{\text {th }}$ year of the project lifetime, there is an increase in the electricity revenue as the debt has been paid in first 15 years. Figure 13 shows the cumulative cash flows of the project. For a lifetime of 20 years. It can clearly be seen in the cumulative cash flow diagram that the project earns its all the occurred cost in 3.1 years. At the end of the $15^{\text {th }}$ year there is a growth in the cumulative cash flow because of the absence of the debt payment.

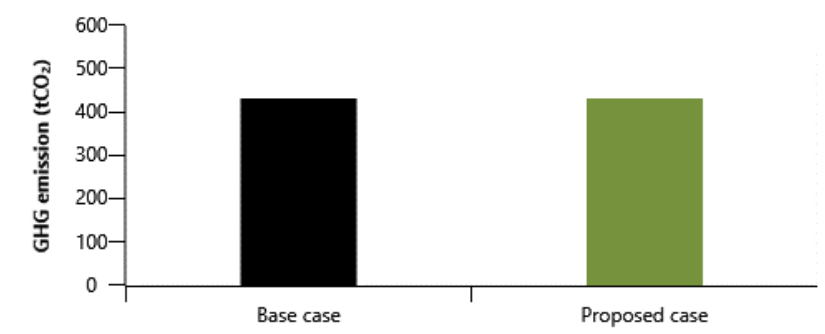

1Il Gross annual GHG emission reduction (100\%)

Figure 14: Gross annual GHG emission reduction

\subsection{Emissions}

RETScreen uses the current energy mix of the country to calculate the Green House Gas (GHG) emissions as beseline data. Figure 16 shows the calculation of the $\mathrm{CO}_{2}, \mathrm{CH}_{4}$, and $\mathrm{N}_{2} \mathrm{O}$ emission factors by using the energy mix of the country by percentage of fuel, T\&D losses and the generation efficiency of electricity depending upon the source. RETScreen also calculates the GHG emissions of the proposed project and compares it to the baseline GHG emissions. In the present case, it is shown in Figure 14 that $433.7 \mathrm{tCO}_{2}$ is emitted in the baseline whereas the is no emission in the proposed micro hydro energy system. There is $100 \%$ reduction of the gross annual emissions in the proposed system.

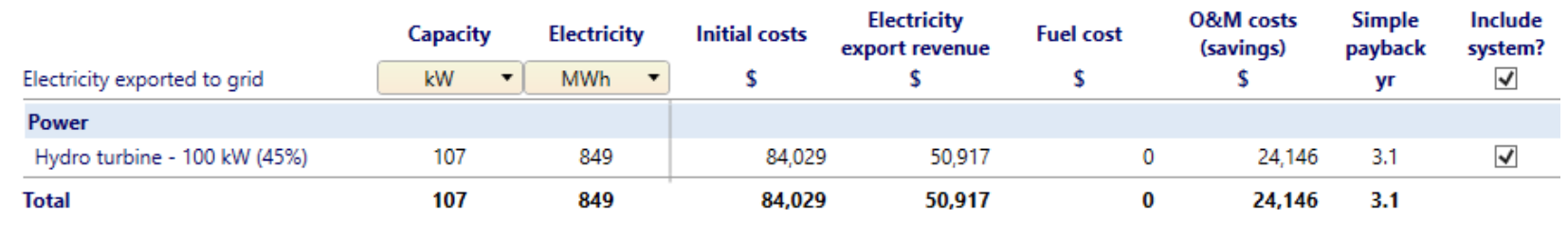

Figure 15: Summary of the proposed system

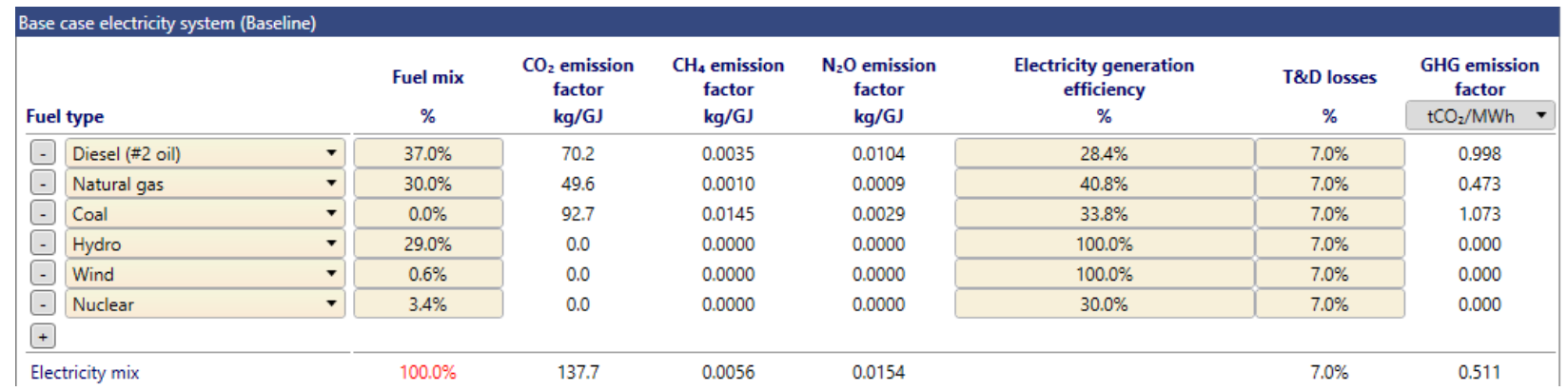

Figure 16: Base case electricity system 


\section{Conclusion}

Hydropower is the cheapest and abundant source of energy in the country. Large hydropower is the proven technology in the country whereas the micro hydro is the old but not explored source of energy. As the micro hydro does not involve any major civil works, it is an early commissioning project. This paper presents the designing of the micro hydropower system for the proposed location of the Jalala Disty canal, and optimization of the proposed system in the RETScreen Expert. RETScreen simulated a micro hydro system of $107 \mathrm{~kW}$ for a lifetime of 20 years. The proposed micro hydropower project is a technically viable and financially feasible based on the Net Present Value (NPV) of 139,280 , Cost of Energy (COE) of $0.049 \mathrm{kWh} / \mathrm{S}$, cumulative cash flows of 400,000 \$, and a payback period of 3.1 years. The paper will be a source of inspiration for the local investors and will attract foreign investors in the field of renewable energy in Pakistan.

\section{References}

[1] M. Kamran, Current status and future success of renewable energy in Pakistan, Renew. Sustain. Energy Rev. $82 \quad$ (2018) 609-617. doi:10.1016/j.rser.2017.09.049.

[2] M.Kamran, M.R.Fazal, M.Mudassar. Towards empowerment of the renewable energy sector in Pakistan for sustainable energy evolution: A SWOT analysis. Renewable Energy. 146 (2020) 543-558.

[3] O. Paish, Micro-hydropower: status and prospects, J. Power Energy. $216 \quad$ (2002) 31-40. doi:10.1243/095765002760024827.

[4] R. Baños, F. Manzano-Agugliaro, F.G. Montoya, C. Gil, A. Alcayde, J. Gómez, Optimization methods applied to renewable and sustainable energy: A review, Renew. Sustain. Energy Rev. 15 (2011) 1753-1766. doi:10.1016/j.rser.2010.12.008.

[5] S. Derakhshan, A. Nourbakhsh, Experimental study of characteristic curves of centrifugal pumps working as turbines in different specific speeds, Exp. Therm. Fluid Sci. $\quad 32 \quad$ (2008) 800-807. doi:10.1016/j.expthermflusci.2007.10.004.

[6] REN21, Renewables 2016-Global Status Report, REN 21, Secretariat, Paris, 2016.

[7] R. Archetti, Micro Hydroelectric Power: Feasibility of a Domestic Plant, Procedia Eng. 21 (2011) 8-15. doi:10.1016/j.proeng.2011.11.1981.

[8] M. Valipour, A comprehensive study on irrigation management in Asia and Oceania, Arch. Agron. Soil $\begin{array}{llll}\text { Sci. } & 61 & \text { (2015) } & \text { 1247-1271. }\end{array}$ doi:10.1080/03650340.2014.986471.

[9] C.P. Jawahar, P.A. Michael, A review on turbines for micro hydro power plant, Renew. Sustain. Energy Rev. $\quad 72 \quad$ (2017) 882-887. doi:10.1016/j.rser.2017.01.133.

[10] M. Valipour, M.A.G. Sefidkouhi, S. Eslamian, Surface irrigation simulation models: a review, Int. J. Hydrol. Sci. Technol. 5 (2015) 51. doi:10.1504/IJHST.2015.069279.

[11] A.M.A. Haidar, M.F.M. Senan, A. Noman, T. Radman, Utilization of pico hydro generation in domestic and commercial loads, Renew. Sustain. Energy Rev. $16 \quad$ (2012) 518-524. doi:10.1016/j.rser.2011.08.017.

[12] J.I. Höffken, Demystification and localization in the adoption of micro hydro technology: Insights from India, Energy Res. Soc. Sci. 22 (2016) 172-182. doi:10.1016/j.erss.2016.09.002.

[13] A. Vyas, N.K. Gupta, S.K. Gupta, P. Gautam, A.S. Jethoo, Mini/Micro Hydel Power System Design and its Implementation in Rajasthan, Aquat. Procedia. 4 (2015) 1537-1544. doi:10.1016/j.aqpro.2015.02.199.

[14] D.A. Zema, A. Nicotra, V. Tamburino, S.M. Zimbone, A simple method to evaluate the technical and economic feasibility of micro hydro power plants in existing irrigation systems, Renew. Energy. 85 (2016) 498-506. doi:10.1016/j.renene.2015.06.066.

[15] M. Kamran, R. asghar, M.Mudassar, M.I.Abid. Designing and economic aspects of run off canal based microhydro system on balloki sulamanki link canal I for remote villages in Punjab, Pakistan., Renewable Energy. 35 (2019).

[16] S.P. Adhau, R.M. Moharil, P.G. Adhau, Mini-hydro power generation on existing irrigation projects: Case study of Indian sites, Renew. Sustain. Energy Rev. $\quad 16 \quad$ (2012) 4785-4795. doi:10.1016/j.rser.2012.03.066.

[17] M. Farooq, A. Shakoor, Severe energy crises and solar thermal energy as a viable option for Pakistan, J. Renew. Sustain. Energy. 5 (2013) 13104. doi:10.1063/1.4772637.

[18] A. Ghafoor, T. ur Rehman, A. Munir, M. Ahmad, M. Iqbal, Current status and overview of renewable energy potential in Pakistan for continuous energy sustainability, Renew. Sustain. Energy Rev. 60 (2016) 1332-1342. doi:10.1016/j.rser.2016.03.020.

[19] A. Ghafoor, A. Munir, Design and economics analysis of an off grid PV system for household electrification, Renew. Sustain. Energy Rev. 42 (2015) 496-502. doi:10.1016/j.rser.2014.10.012.

[20] U.K. Mirza, N. Ahmad, T. Majeed, K. Harijan, Hydro power use in Pakistan: Past, present and 
future, Renew. Sustain. Energy Rev. 12 (2008) 1641-1651. doi:10.1016/j.rser.2007.01.028.

[21] W. Raza, H. Saulat, S.U. Islam, M. Ayub, M. Saleem, N. Raza, Renewable energy resources current status and barriers in their adaptation for Pakistan, J. Bioprocess. Chem. Eng. 3 (2015) 1-9.

[22] M. Asif, Sustainable energy options for Pakistan, Renew. Sustain. Energy Rev. 13 (2009) 903-909. doi:10.1016/j.rser.2008.04.001.

[23] NEPRA, State of Industry Report. Islamabad, National Electric Power Regulatory Authority. (2014).

[24] A. Batool, F. Abbas, Reasons for delay in selected hydro-power projects in Khyber Pakhtunkhwa (KPK), Pakistan, Renew. Sustain. Energy Rev. 73 (2017) 196-204. doi:10.1016/j.rser.2017.01.040.

[25] NEPRA, State of Industry Report. Islamabad, National Electric Power Regulatory Authority. (2011).

[26] M.Kamran, M.Mudassar, et al. Socio-Economic Acceptance for Stand-Alone Solar PV Systems: Surv. ey Evidence from Southern Punjab, Pakistan. International Journal of Renewable Energy Research. 9 (2019) 302-308.

[27] AEDB, Potential and progress inSmall Hydro power, Altern. Energy Dev. Board. (n.d.). http://www.aedb.org/index.php/aetechnologies/small-hydro (accessed June 2, 2017).

[28] GoP.Energy Department, Opportunities in Punjab Hydro, (2017). http://www.energy.punjab.gov.pk/_pages/oppinPunja b_Hydro.html (accessed October 23, 2017).

[29] HOMER, HOMER Pro version 3.7 User Manual, HOMER Energy. (2016).
[30] M.Kamran, M.R. Fazal, M.Mudassar, et al. Solar Photovoltaic Grid Parity: A Review of Issues and Challenges and Status of Different PV Markets. International Journal of Renewable Energy Research. 9 (2019) 244-260.

[39] O. Paish, Small hydro power: technology and current status, Renew. Sustain. Energy Rev. 6 (2002) 537 556. doi:10.1016/S1364-0321(02)00006-0.

[40] S. Bahramara, M.P. Moghaddam, M.R. Haghifam, Optimal planning of hybrid renewable energy systems using HOMER: A review, Renew. Sustain. Energy Rev. $62 \quad$ (2016) 609-620. doi:10.1016/j.rser.2016.05.039.

[41] Y.A. Katsigiannis, P.S. Georgilakis, E.S. Karapidakis, Genetic Algorithm Solution to Optimal Sizing Problem of Small Autonomous Hybrid Power Systems, in: Springer, Berlin, Heidelberg, 2010: pp. 327-332. doi:10.1007/978-3-642-12842-4_38.

[42] HOMER, Levelized Cost of Energy, Natl. Renew. Energy Lab. (2017). https://www.homerenergy.com/support/docs/3.10/lev elized_cost_of_energy.html (accessed November 1, 2017).

[43] V. Khare, S. Nema, P. Baredar, Optimisation of the hybrid renewable energy system by HOMER, PSO and CPSO for the study area, Int. J. Sustain. Energy. 36 (2017) 326-343. doi:10.1080/14786451.2015.1017500.

[44] M.K. Shahzad, A. Zahid, T. ur Rashid, M.A. Rehan, M. Ali, M. Ahmad, Techno-economic feasibility analysis of a solar-biomass off grid system for the electrification of remote rural areas in Pakistan using HOMER software, Renew. Energy. 106 (2017) 264273. doi:10.1016/j.renene.2017.01.033. 